\title{
ANALYSIS OF PROTEINS OF BOVINE LENS, VITREOUS, AND AQUEOUS BY ELECTROPHORESIS AND BY OUDIN'S GEL DIFFUSION TECHNIQUE*
}

\author{
BY
}

\author{
S. S. RAO AND M. E. KULKARNI \\ Haffkine Institute, Bombay \\ AND
}

\author{
S. N. COOPER AND M. R. RADHAKRISHNAN \\ G. S. Medical College and King Edward VII Memorial Hospital, Bombay
}

THE object of these studies was to analyse the proteins of bovine crystalline lens, aqueous, and vitreous humour to find out whether there are proteins common to these tissues and to bovine serum. Apart from the theoretical interest, there was also the practical aspect that the results might throw some light on the problem of endophthalmitis phacoanaphylactica.

Verhoeff and Lemoine (1922), Burky and Woods (1931), and Woods and Burky (1933) have suggested that this allergic condition is due to sensitization by the patient's own lens material after lenticular injury. This could happen only if the lens contained proteins dissimilar to blood proteins. Successful attempts have been made by Burky and Henton (1936) to desensitize patients with endophthalmitis phacoanaphylactica by using a mixture of bovine lens and staphylococcus toxin. Berens and Bogart (1938) used this desensitization technique of Burky and Henton (1936) successfully in five patients. Cooper, Lakhani, and Jhaveri (1948) reported similar results.

We have analysed the proteins of lens, vitreous, and aqueous by electrophoresis, and by the immunological technique of Oudin (1947).

Electrophoresis of bovine lens proteins was carried out by Hesselvik (1939) and by Viollier, Labhart, and Süllmann (1947) who found two proteins present. The faster moving component was identified as the alpha-crystallin and the slower as beta-crystallin.

Hesselvik (1939) also examined bovine vitreous humour electrophoretically and found three components. The fastest was thought to be hyalomucoid and the slowest had the same mobility as the serum gamma-globulin; the mobility of the third was slightly faster than that of human or horse serum albumin. Cagianut and Wunderly (1953) who recently used paper electrophoresis in the analysis of human vitreous reported that it gives a pattern similar to that of serum.

Von Sallmann and Moore (1948) analysed concentrated normal bovine and rabbit aqueous humour by electrophoresis and observed a fast moving component not apparent in serum, and only two globulin components. However, the aqueous from inflamed rabbit eyes had the same number of components as rabbit serum. Witmer (1953) has recently reported that the

*Received for publication February 15, 1954. 
aqueous of human pathological cases resembled normal human serum when examined by paper electrophoresis.

It cannot be asserted that proteins from two different sources having the same electrophoretic mobility are the same proteins. The fact that some proteins in vitreous and aqueous have the same mobility as serum proteins does not necessarily mean that the same protein occurs in these solutions. Conclusive evidence on this point can, however, be derived from an immunological method. The antigen-antibody diffusion technique first proposed by Oudin (1947) was developed by other workers, especially Munoz and Becker (1950), Pope, Stevens, Caspary, and Fenton (1951), Bowen (1952), and Oakley and Fulthorpe (1953). The technique is simple and reliable and consists in allowing antigen and its antibody to diffuse towards each other through an intervening layer of agar gel. The number of lines or bands formed in the middle layer gives the minimum number of antigens in the material. Common proteins are detected by using an anti-sera prepared by immunizing with one substance against the other.

\section{Methods}

Bovine eyes were collected immediately after slaughter, and brought to the iaboratory in an ice box. In the laboratory, the aqueous was first removed with a sterile syringe and collected in a sterile container. A transverse cut was made in the cornea and the lens with the capsule expelled and collected in a sterile bottle containing glass beads. The vitreous was then pressed out through the cornea and also collected in a sterile bottle containing glass beads. The time taken from the collection of the eyes at the slaughter house to processing in the laboratory was not more than 2 to 3 hours.

Preparation of Soluble Lens Proteins.-The method of Woods and Burky (1927) was followed with slight modifications. The lenses were washed lightly with saline. To twenty lenses weighing $39 \mathrm{gm} .400 \mathrm{ml}$. N/100 ammonium hydroxide was added and shaken for a few hours with the glass beads in a shaking machine. The solution was then centrifuged at high speed $\left(10,000\right.$ gravity) at $5^{\circ} \mathrm{C}$. The supernatant fluid was filtered through Seitz sterilizing pads. The filtrate analysed 3.36 per cent. total solids, $0.508 \mathrm{~g}$. per cent. total nitrogen, and $0.0405 \mathrm{~g}$. per cent. non-protein nitrogen (NPN).

Alpha-crystallin was isolated according to the method of Woods and Burky (1927) by isoelectric precipitation at $p \mathrm{H} 4.8$ from dialysed solutions of lens proteins. It was dissolved by adding a few drops of $\mathrm{N} / 10$ sodium hydroxide and was precipitated twice at $p \mathrm{H} 4 \cdot 8$.

$140 \mathrm{ml}$. aqueous were obtained from one hundred bovine eyes. It contained $1 \cdot 173$ per cent. total solids, $46 \mathrm{mg}$. per cent. total nitrogen, $13 \mathrm{mg}$. per cent. NPN, and $700 \mathrm{mg}$. per cent. chloride as $\mathrm{NaCl}$. It was then dialysed against running distilled water in the cold room for 5 days. The dialysed solution contained 0.13 per cent. total solids, $20 \mathrm{mg}$. per cent. total nitrogen, $0.4 \mathrm{mg}$. per cent. NPN, and only traces of chlorides. This was concentrated fifteen times to about 2 per cent. total solide by putting it inside cellophane tubing and suspending it in the cold room in front of a fan. A few drops of toluene served as a preservative.

$900 \mathrm{ml}$. vitreous humour were obtained from one hundred bovine eyes, and shaken with glass beads for 2 hours until it liquefied. The solution was filtered through Seitz pads. The filtrate analysed 1.2 per cent. total solids, $66 \mathrm{mg}$. per cent. total nitrogen, $13.4 \mathrm{mg}$. per cent. NPN, and $720 \mathrm{mg}$. per cent. chlorides as $\mathrm{NaCl}$. After dialysis in the cold room it contained 0.29 per cent. total solids, $46 \mathrm{mg}$. per cent. total nitrogen, $0.1 \mathrm{mg}$. per cent. 
NPN, and traces of chlorides. The dialysed vitreous was concentrated seven times to about 2 per cent. total solids, using the technique described for aqueous.

Preparation of Antisera.- Rabbits were used for the preparation of antisera against:

(a) Seitz filtered soluble whole lens solution,

(b) dialysed aqueous concentrated to about 2 per cent. solids,

(c) dialysed vitreous concentrated to about 2 per cent. solids.

The rabbits were given twice weekly subcutaneous injections of the appropriate antigen in the series, $0 \cdot 1,0 \cdot 2,0 \cdot 5,1 \cdot 0,1 \cdot 5$, and $2 \mathrm{ml}$. After this, the rabbits received weekly injections of $2 \mathrm{ml}$. subcutaneously, and at the same time in the same increasing series as above (i.e. 0.1-2 ml.) intravenously. One week after the final injection $20 \mathrm{ml}$. blood was taken from the heart of each animal. A week later the previous injection of antigen solution was repeated, and a week later a second bleeding of $20 \mathrm{ml}$. was taken. This was repeated for ten to fifteen bleedings after which the rabbits were rested. The sera were preserved with 0.01 per cent. merthiolate and stored in a refrigerator.

\section{Procedure}

Electrophoresis was carried out in the Hilger electrophoresis apparatus. The dialysed solutions of normal bovine serum, whole lens, alpha-crystallin, whole lens minus alpha-crystallin, aqueous, and vitreous, were adjusted to roughly 2 per cent. proteins $(\mathrm{N} \times 6 \cdot 25)$. They were then dialysed against barbiturate buffer ( $p \mathrm{H} 8.6$ and ionic strength $0 \cdot 1$ ) for $48 \mathrm{hrs}$ in the cold room. The exact concentration of proteins in each solution was determined by evaporation at $102^{\circ} \mathrm{C}$. and subtracting the weight due to buffer salts. Electrophoresis was carried out in the same buffer with a current of 15 milliamps and a potential gradient of about 4 volts per centimetre. Ascending patterns were photographed from time to time during electrophoresis. Figs 1 to 6 (overleaf) show the electrophoretic patterns of the solutions in the order given above.

Immunological Technique of Oudin.-The procedure used was a slight modification of the method of Bowen (1952). A stock solution of 1.6 per cent. filtered merthiolated agar was maintained in a fluid state at $50^{\circ} \mathrm{C}$. To this was added the undiluted antisera in the ratio of $0.7 \mathrm{ml}$. antisera to $0.3 \mathrm{ml}$. melted agar; $0.5 \mathrm{ml}$. of this mixture was poured carefully into narrow tubes 8 to $10 \mathrm{~mm}$. in diameter and 8 to $10 \mathrm{~cm}$. long. When the layer had set, the tubes were kept in the cold for hardening. A second layer of $1 \mathrm{ml}$. plain filtered 0.8 per cent. merthiolated agar was then poured over the first layer and allowed to set; $0.5 \mathrm{ml}$. dialysed and concentrated antigen containing about 2 per cent. solids was then added and the tubes were kept in the cold room for 2 days after which they were sealed and kept in an incubator at $37^{\circ} \mathrm{C}$. The number and intensity of the bands of antigenantibody precipitate in the middle layer were read on the $3 \mathrm{rd}, 7 \mathrm{th}$, and 15 th days. The number of bands represents the minimum number of antigens for which there are antibodies in the sera used. The intensity of a band indicates roughly the concentration of that antigen. The position of a band depends on the relative concentration of antigen and its antibody (Fig. 7).

The Table (overleaf) gives the number of bands obtained with the different antigens and antibodies.

\section{Interpretation of Results of Electrophoresis}

The electrophoretic pattern of normal bovine serum (Fig. 1) resembles that of any mammalian sera ; it consists of albumin, alpha-1-globulin, alpha2-globulin, beta-globulin, and gamma-globulin. 


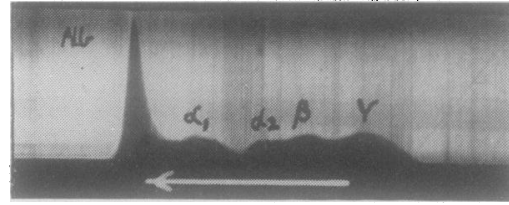

Fig. 1.-Normal bovine serum. Electrophoretic pattern after $210 \mathrm{~min}$. Total protein 2.52 per cent.

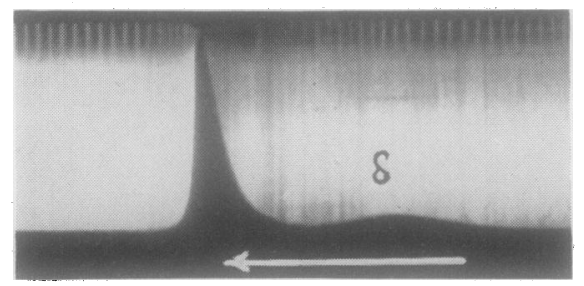

Fig. 3.-Bovine alpha-crystallin. Electrophoretic pattern after $150 \mathrm{~min}$. Total protein 2.05 per cent.

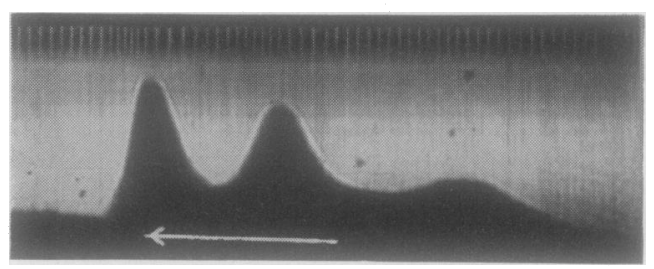

FIG. 5.-Aqueous humour. Electrophoretic pattern after $240 \mathrm{~min}$. Total protein 1.91 per cent.

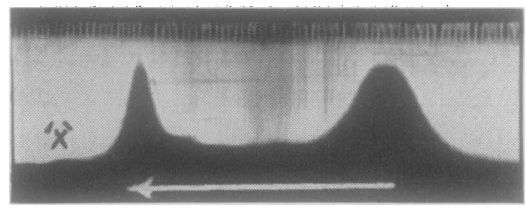

Fig. 6.-Vitreous humour. Electrophoretic pattern after $240 \mathrm{~min}$ Total protein 1.76 per cent.

Soluble proteins of whole lens (Fig. 2) showed three peaks during electrophoresis. These probably represent the three proteins isolated by Burky and Woods(1928), namely, alpha-crystallin, beta-crystallin, and gamma

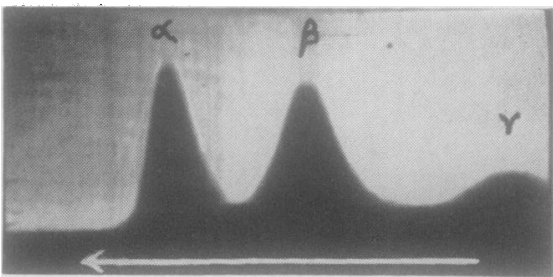

Fig. 2.-Bovine whole lens. Electrophoretic pattern after $210 \mathrm{~min}$. Total protein $2 \cdot 17$ per cent.

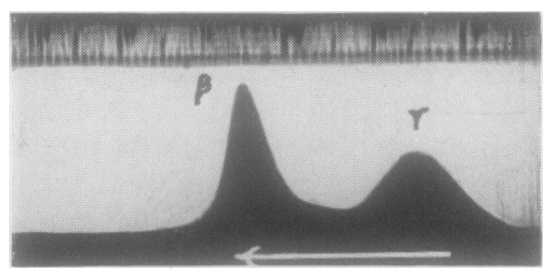

Fig. 4.-Whole lens proteins minus alphacrystallin. Electrophoretic pattern after $210 \mathrm{~min}$. Total protein 1.92 per cent.

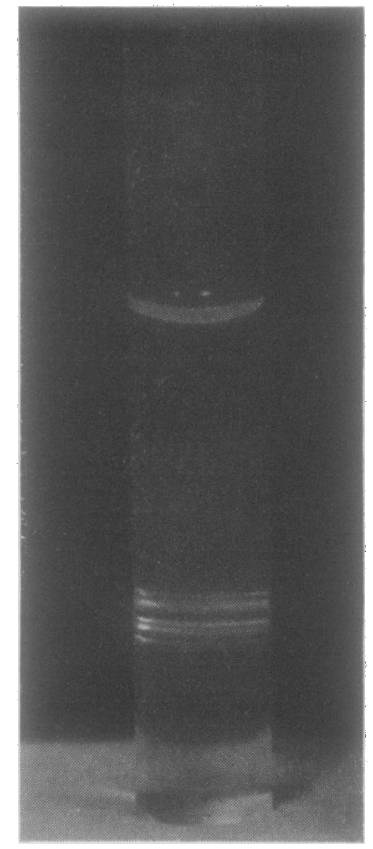

Fig. 7.-Oudin's agar diffusion technique. Bottom layer: Anti-vitreous serum. Top layer: Bovine serum. 
TABLE

RESULTS OF OUDIN GEL DIFFUSION TECHNIQUE

\begin{tabular}{|c|c|c|c|c|c|c|}
\hline \multirow{2}{*}{ No. } & \multirow{2}{*}{ Antibody } & \multirow{2}{*}{ Antigen } & \multicolumn{4}{|c|}{ Number of Lines } \\
\hline & & & Intense & Medium & Faint & Total \\
\hline 1 & Whole Lens & Whole Lens & 2 & 1 & 3 & 6 \\
\hline 2 & & Alpha Crystallin & 1 & - & 1 & 2 \\
\hline 3 & & $\begin{array}{l}\text { Whole minus Alpha } \\
\text { Crystallin }\end{array}$ & 1 & - & 2 & 3 \\
\hline 4 & & Vitreous & - & - & 2 & 2 \\
\hline 5 & & Bovine Serum & - & - & - & Nil \\
\hline 6 & Aqueous & Aqueous & 4 & - & 2 & 6 \\
\hline 7 & & Whole Lens & 1 & 2 & - & 3 \\
\hline 8 & & Alpha Crystallin & - & 1 & 1 & 2 \\
\hline 9 & & Vitreous & 2 & 1 & - & 3 \\
\hline 10 & & Bovine Serum & - & 1 & 2 & 3 \\
\hline 11 & Vitreous & Vitreous & 3 & 1 & 1 & 5 \\
\hline 12 & & Whole Lens & - & 1 & 1 & 2 \\
\hline 13 & & Alpha Crystallin & - & - & 2 & 2 \\
\hline 14 & & Aqueous & - & 3 & 2 & 5 \\
\hline 15 & & Bovine Serum & 2 & 3 & - & 5 \\
\hline
\end{tabular}

crystallin. The fastest moving component contains the alpha-crystallin, since its mobility corresponds with that calculated for the purified alphacrystallin (Fig. 3). The small peak in the photograph of alpha-crystallin (Fig. 3) is probably due to the delta boundary, which is to be found at the starting position.

The electrophoretic pattern of whole lens minus alpha-crystallin (Fig. 4) shows that it is free from alpha-crystallin and consists of only two peaks corresponding to the beta- and gamma-crystallins.

The electrophoretic pattern of concentrated aqueous humour (Fig. 5) resembles that of whole lens and also consists of three peaks. The mobilities of the three components of aqueous correspond with those of whole lens.

Vitreous humour (Fig. 6) has an electrophoretic pattern which resembles that of serum rather than that of whole lens or aqueous, but vitreous has larger amounts of gamma-globulin than serum. There is also a very small amount of a protein marked " $\mathrm{X}$ " which has higher mobility than albumin; this is possibly the hyalomucoid of Hesselvik (1939). 


\section{Interpretation of Results of Oudin's Gel Diffusion Technique}

It may be repeated here that the number of bands reveals the minimum number of antigens in each preparation. Since a single band may in fact be formed by the superimposition of two or more bands, there may be more antigens than indicated by the number of bands. Moreover, if the concentration of antigen as well as its antibody is very low, that is, below the precipitating concentration, there will be no formation of bands.

From the Table we may draw the following conclusions:

(a) Bovine lens has three proteins in large amounts, probably alpha-, beta-, and gamma-crystallins, and three other proteins in very small amounts. None of these proteins is antigenically related to bovine serum proteins.

(b) Aqueous humour consists of at least six proteins, three in common with lens proteins and the other three with serum proteins.

(c) Vitreous humour consists of at least seven proteins, five in common with serum proteins and at least two with lens proteins.

\section{Discussion}

Our results show that lens proteins differ antigenically from blood proteins. This may explain the possibility of sensitization to one's own lens protein resulting in the pathological condition of endophthalmitis phacoanaphylactica.

Electrophoresis shows that normal aqueous protein is largely derived from the lens since the electrophoretic pattern is similar to that of the lens. This is supported by results obtained by the "Oudin " technique, which also shows that the aqueous contains small amounts of serum proteins. In inflamed eyes and in pathological cases, however, the aqueous might resemble serum in composition as reported by von Sallmann and Moore (1948) and Witmer (1953). Normal vitreous humour proteins, on the other hand, are made up largely of blood proteins since the electrophoresis pattern resembles that of serum. The vitreous also contains small amounts of lens protein, as revealed by the "Oudin" technique.

These results suggest that not only injury to the lens but also any injury which causes aqueous or vitreous proteins to enter the blood stream can cause sensitization to lens proteins. This may explain the hypersensitive cutaneous reaction to lens protein shown by 8 per cent. of patients tested by Verhoeff and Lemoine (1922).

The presence of lens proteins and a large proportion of non-protein nitrogen in aqueous suggests that lens proteins may be excreted into the aqueous through the lens capsule and destroyed by the proteolytic enzymes which are known to be present in the aqueous (Krause, 1933); the degraded non-antigenic products would then diffuse into the blood. If the lens proteins were not so destroyed, anaphylaxis from this source would be extremely common. 


\section{Summary}

(1) The proteins of bovine lens, aqueous, and vitreous were examined by electrophoresis and by Oudin's antigen-antibody diffusion technique.

(2) The lens proteins were found to be antigenically different from serum proteins.

(3) Normal aqueous was found to contain lens proteins and small amounts of blood proteins.

(4) Vitreous was found to contain serum proteins and small amounts of lens proteins.

(5) The significance of these results in the causation of endophthalmitis phacoanaphylactica is discussed.

The authors are grateful to the Indian Council of Medical Research for the award of a research grant to one of us (S.N.C.), to Dr. A. K. Hazra for his keen interest, to Mr. K. P. Prabhu and Dr. T. N. Ursekar for help during the course of this work, and to Dr. P. M. Wagle, Director of the Haffkine Institute, and Dr. R. G. Dhayagude, Dean of the G. S. Medical College, and the King Edward VII Memorial Hospital, for providing laboratory facilities.

\section{REFERENCES}

Berens, C., and Bogart, D. W. (1938). Amer. J. Surg., 42, 39.

BOWEN, H. E. (1952). J. Immunol., 68, 429.

Burky, E. L., and Henton, H. C. (1936). Amer. J. Ophthal., 19, 782.

- and Woods, A. C. (1928). Arch. Ophthal. (Chicago), 57, 464.

$\longrightarrow$ - (1931). Ibid., 6, 548.

CAgIANut, B., and WunderLy, C. (1953). British Journal of Ophthalmology, 37, 229.

Cooper, S. N., Lakhani, K. G., and Jhaveri, B. N. (1948). Proc. All-India ophthal. Soc., 9, 35. Hesselvik, L. (1939). Skand. Arch. Physiol., 82, 151-156.

Krause, A. C. (1933). Arch. Ophthal. (Chicago), 10, 631.

MUNOZ, J., and BECKER, E. L. (1950). J. Immunol., 65, 47.

OAkley, C. L., and FulthorPe, A. L. (1953). J. Path. Bact., 65, 49.

Oudin, J. (1947). Bull. Soc. Chim. biol. (Paris), 29, 140.

Pope, C. G., Stevens, M. F., Caspary, E. A., and Fenton, E. L. (1951). Brit. J. exp. Path., 32, 246.

Sallmann, L. von, and Moore, D. H. (1948). Arch. Ophthal. (Chicago), 40, 279.

VerHOEFF, F. H., and LeMOINe, A. N. (1922). Proc. Int. Congr. Ophthal. (Washington D.C.), p. 234-284.

Viollier, G., Labhart, H., and Süllmann, H. (1947). Helv. physiol. pharmacol. Acta., 5, C10.

WITMER, R. H. (1953). J. All-India ophthal. Soc., 1, 15.

Woods, A. C., and Burky, E. L. (1927). J. Amer. med. Ass., 89, 102.

- L. (1933). Amer.J. Ophthal., 16, 951. 